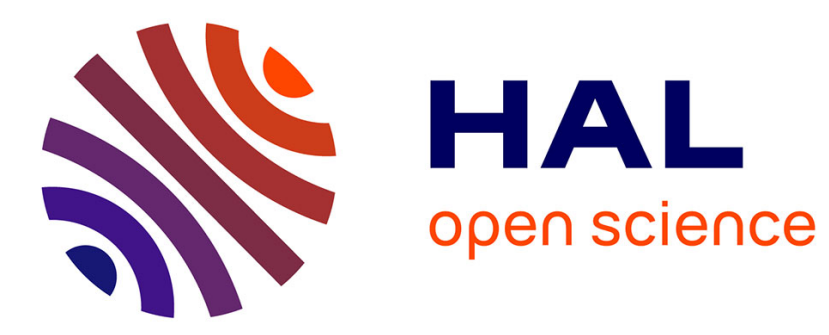

\title{
A Study of Damage during Impact in Zerodur
}

\author{
H. Senf, E. Strassburger, H. Rothenhäusler
}

\section{To cite this version:}

H. Senf, E. Strassburger, H. Rothenhäusler. A Study of Damage during Impact in Zerodur. Journal de Physique IV Proceedings, 1997, 07 (C3), pp.C3-1015-C3-1020. 10.1051/jp4:19973171 . jpa-00255463

\section{HAL Id: jpa-00255463 https://hal.science/jpa-00255463}

Submitted on 1 Jan 1997

HAL is a multi-disciplinary open access archive for the deposit and dissemination of scientific research documents, whether they are published or not. The documents may come from teaching and research institutions in France or abroad, or from public or private research centers.
L'archive ouverte pluridisciplinaire HAL, est destinée au dépôt et à la diffusion de documents scientifiques de niveau recherche, publiés ou non, émanant des établissements d'enseignement et de recherche français ou étrangers, des laboratoires publics ou privés. 


\title{
A Study of Damage during Impact in Zerodur
}

\author{
H. Senf, E. Strassburger and H. Rothenhäusler \\ Fraunhofer Institut für Kurzzeitdynamik, Ernst-Mach-Institut (EMI), Hauptstrasse 18, \\ 79576 Weil am Rhein, Germany
}

\begin{abstract}
The damage evolution in the transparent glass-ceramic ZERODUR, when impacted by pointed and blunt steel cylinders, was investigated in a high-speed photographic study. The impact velocities were varied in the range from $50 \mathrm{~m} / \mathrm{s}$ to $1500 \mathrm{~m} / \mathrm{s}$. Crack velocities and damage velocities were measured by means of the sequences of shadowgraphs, taken with a Cranz-Schardin camera. The damage velocities and the threshold for nucleation of fracture were determined as a function of impact velocity. The results showed, that the glass-ceramic ZERODUR exhibits similar damage mechanisms as observed with different types of glasses in earlier work. The ballistic efficiency of the material was determined by means of Depth of Penetration (DOP) tests.
\end{abstract}

\begin{abstract}
Résumé: L'évolution de l'endommagement a été étudié pour la céramique vitreuse ZERODUR a l'aide d'une caméra ultra-rapide. Les essais avec impact sur les bords furent réalisés avec des cylindres d'acier dans la gamme de vitesse d'impact de $50 \mathrm{~m} / \mathrm{s}$ à $1500 \mathrm{~m} / \mathrm{s}$. Les vitesses de propagation des fissures et de l'enđommagement ont été mésurés à l'aide d'images ombroscopique obtenus avec la caméra CranzSchardin. Les vitesses de l'endommagement et le seuil pour nucléation ont été déterminée en fonction de la vitesse d'impact. Les résultats ont démontrés des mécanismes d'endommagement simulaires avec ZERODUR qu'avec les types de verre utilisés dans des traveaux ultérieurs. L'éfficacité ballistique du matériau était déterminée par des tests DOP (Depth of Penetration).
\end{abstract}

\section{INTRODUCTION}

The glass-ceramic ZERODUR ${ }^{T M}$ exhibits not only a high hardness but also a high degree of transparency. The transmission of light is $90-70 \%$ for layers of thickness in the range from $5 \mathrm{~mm}$ to $25 \mathrm{~mm}$. The combination of those two qualities could make this material a candidate for applications in the field of transparent armour. For this reason the dynamic fracture behaviour of ZERODUR during impact of steel projectiles was investigated in a high-speed photographic study. In order to visualise fracture the edge-on impact configuration was chosen, which had been employed successfully in earlier studies of fracture and damage propagation in glasses [1]. Additionally, the ballistic efficiency of ZERODUR was assessed by means of Depth of Penetration (DOP) tests, where the residual penetration into a steel block is measured after the projectile has perforated a layer of the test material

\section{VISUALISATION OF DAMAGE}

Figure 1 shows a schematic of the edge-on impact configuration. The ZERODUR specimens were impacted by blunt (Diameter $\mathrm{D}=30 \mathrm{~mm}$, Length $\mathrm{L}=23 \mathrm{~mm}$ ) and pointed steel cylinders. The impact velocities were variied in the range from $50 \mathrm{~m} / \mathrm{s}$ to $1500 \mathrm{~m} / \mathrm{s}$. The specimens were of the dimensions 150 $\mathrm{mm} \times 150 \mathrm{~mm} \times 11.4 \mathrm{~mm}$. A compilation of physical and mechanical properties of ZERODUR is given in 
Table 1. The content of crystalline phase $\left(\mathrm{Li}_{2} \mathrm{O}-\mathrm{Al}_{2} \mathrm{O}_{3}-\mathrm{SiO}_{2}\right)$ in ZERODUR is usually between 70 and 78 weight percent. The average size of the crystals is about $50 \mathrm{~nm}$ [2].

Table 1 Physical and mechanical properties of ZERODUR

\begin{tabular}{|l|l|}
\hline Density & $2.53 \mathrm{~g} / \mathrm{cm}^{3}$ \\
\hline Young's Modulus & $91 \mathrm{GPa}$ \\
\hline Poisson ratio & 0.24 \\
\hline Hardness & $750 \mathrm{HV}$ \\
\hline
\end{tabular}

This paper focuses on the damage phenomenology. Crack velocities and damage velocities were measured by means of the sequences of shadowgraphs, taken with a Cranz-Schardin camera. Table 2 shows a list of the experiments.

Table 2 Compilation of experiments

\begin{tabular}{|c|c|c|}
\hline \multicolumn{3}{|c|}{ Blunt projectiles } \\
\hline $\begin{array}{c}\text { Impact velocity } \\
\mathrm{v}_{\mathrm{P}}[\mathrm{m} / \mathrm{s}]\end{array}$ & $\begin{array}{c}\text { Crack velocity } \\
\mathrm{v}_{\mathrm{C}}[\mathrm{m} / \mathrm{s}]\end{array}$ & $\begin{array}{c}\text { Damage velocity } \\
\mathrm{v}_{\mathrm{D}}[\mathrm{m} / \mathrm{s}]\end{array}$ \\
\hline 75 & 2245 & 2245 \\
\hline 90 & 2250 & 3240 \\
\hline 111 & 2190 & 3200 \\
\hline 144 & --- & 4130 \\
\hline 267 & --- & 5120 \\
\hline 1287 & --- & 5526 \\
\hline & Pointed projectiles & \\
\hline 606 & 2287 & 2287 \\
\hline 1445 & 2478 & 2478 \\
\hline
\end{tabular}

In most of the tests blunt projectiles with $30 \mathrm{~mm}$ diameter and $23 \mathrm{~mm}$ length were used. This allows a direct comparison to the data obtained with glasses where the same experimental configuration was employed. The notation introduced for the description of impact damage in glasses and the concept of damage velocity which were described in [1] will also be used here.

As found with glasses, ZERODUR was destroyed only by cracks that were initiated at the impact edge in the range of low impact velocities. Figure 2 shows the fracture pattern of a specimen $16 \mu \mathrm{s}$ after impact at $75 \mathrm{~m} / \mathrm{s}$. Two triangular-shaped secondary crack zones are visible above and below the edge of the projectile. Ahead of the projectile radial cracks and the contours of shell-shaped fragmentation can be recognised.

With impact velocities above $90 \mathrm{~m} / \mathrm{s}$ the nucleation of crack centers can be observed. Figure 3 depicts four phases of the damage evolution. The photographs were taken at $3 \mu \mathrm{s}, 5.1 \mu \mathrm{s}, 6.9 \mu \mathrm{s}$ and $9 \mu \mathrm{s}$ after projectile impact with $v_{p}=144 \mathrm{~m} / \mathrm{s}$. After $3 \mu \mathrm{s}$ only radial cracks and secondary cracks were visible. During the next $6 \mu \mathrm{s}$ the area ahead of the projectile was filled with cracks that emerged from nucleation sites. With higher impact velocities the number of crack centers and the damage velocity increased. This is illustrated in Figure 4, which shows three phases of the damage evolution after impact at $267 \mathrm{~m} / \mathrm{s}$. 


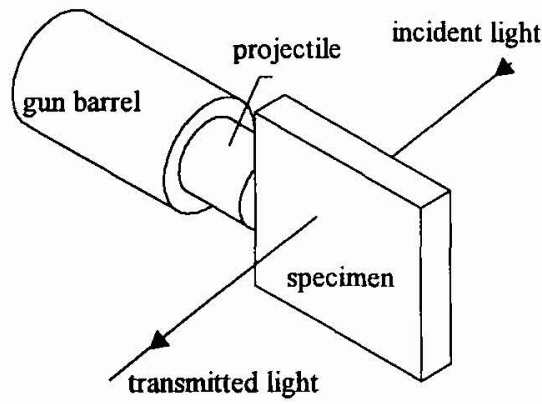

Figure 1: Schematic of experimental configuration
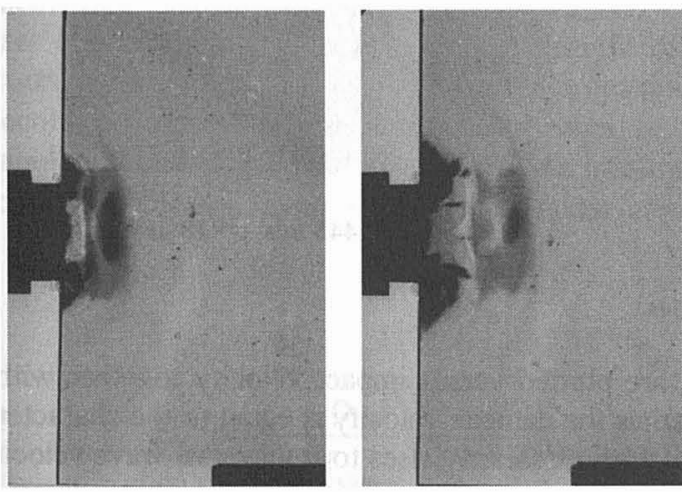

$3 \mu \mathrm{s}$

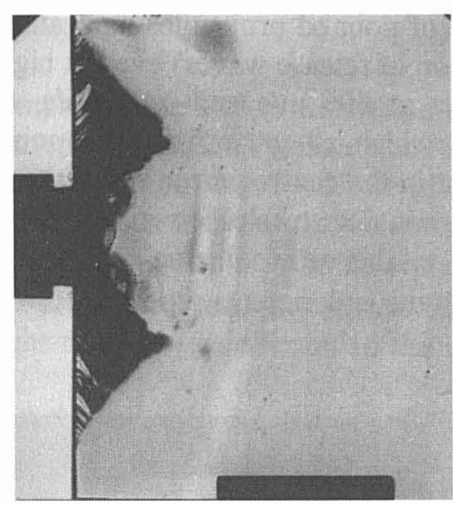

Figure 2:ZERODUR, $16 \mu \mathrm{s}$ after impact at $75 \mathrm{~m} / \mathrm{s}$
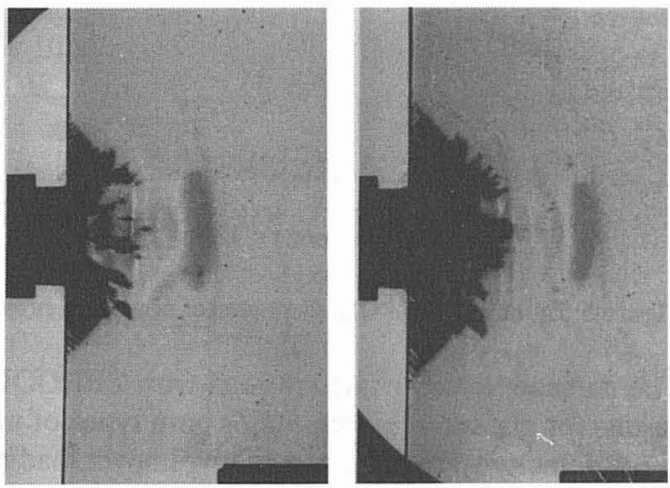

$6.9 \mu \mathrm{s}$

$9 \mu \mathrm{s}$

Figure 3: Four phases of damage in ZERODUR after impact at $144 \mathrm{~m} / \mathrm{s}$

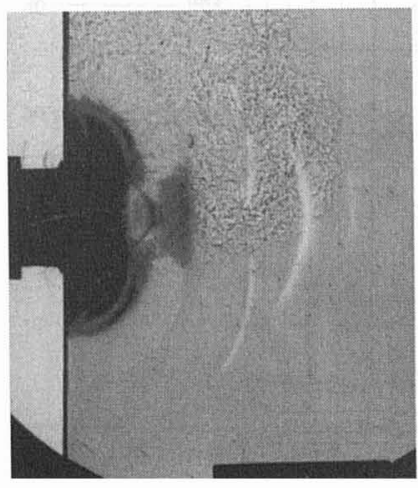

$6.1 \mu \mathrm{s}$

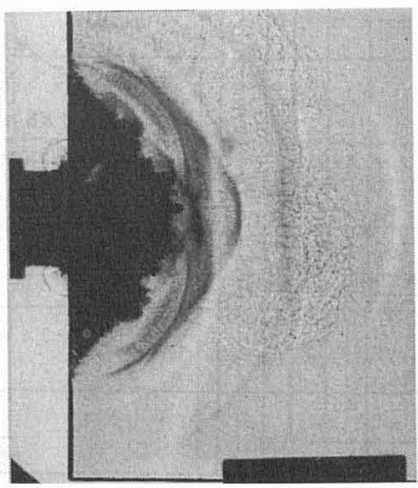

$10.1 \mu \mathrm{s}$

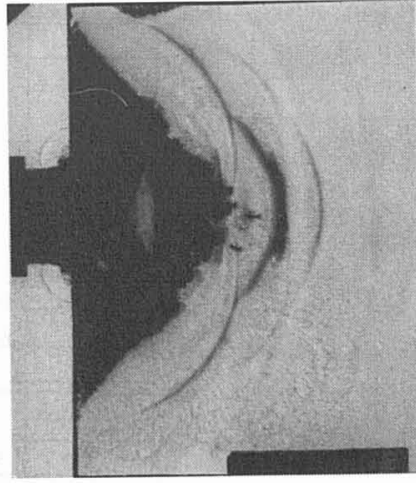

$14 \mu \mathrm{s}$

Figure 4: Three phases of damage in ZERODUR after impact at $267 \mathrm{~m} / \mathrm{s}$ 
In the case of pointed projectiles nucleation could not be initiated in the centre part of the specimens (no superposition of release waves) even at high impact velocities. Figure $5 \mathrm{a}$ and $5 \mathrm{~b}$ show the specimens $18 \mu \mathrm{s}$ after impact at $606 \mathrm{~m} / \mathrm{s}$ and $1445 \mathrm{~m} / \mathrm{s}$, respectively. With $v_{P}=606 \mathrm{~m} / \mathrm{s}$ only radial cracks could be recognised which all grew from the point of impact at the same velocity. The crack front was also semicircular in the centre part in the shot with $v_{P}=1445 \mathrm{~m} / \mathrm{s}$, but there was nucleation visible in the lower part which was due to release waves from the edge of the specimen. In both cases the damage velocity $v_{D}$ was equal to the terminal crack velocity of the material. The average of all measurements of crack velocities in the experiments reported here was $v_{C}=2243 \mathrm{~m} / \mathrm{s} \pm 42 \mathrm{~m} / \mathrm{s}$.

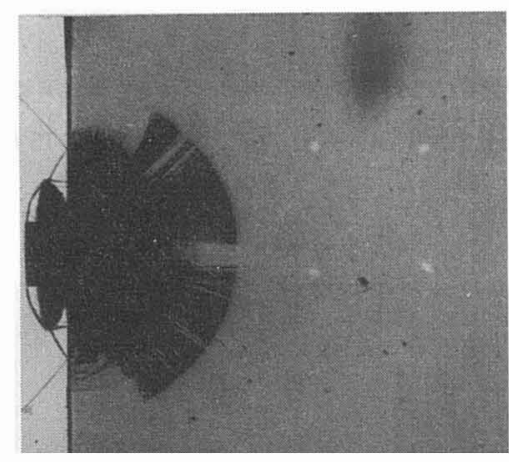

a) $v_{P}=606 \mathrm{~m} / \mathrm{s}, t=18 \mu \mathrm{s}$

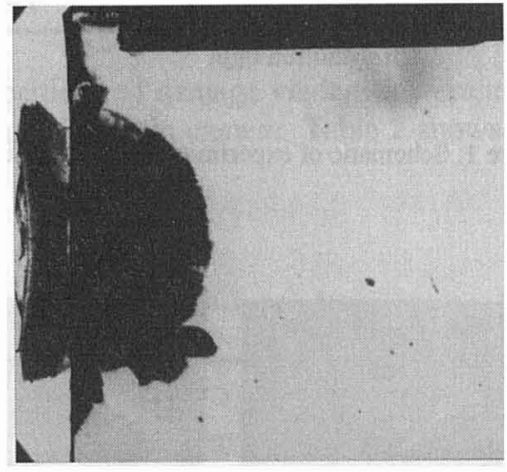

b) $\mathrm{V}_{\mathrm{P}}=1445 \mathrm{~m} / \mathrm{s}, \mathrm{t}=18 \mu \mathrm{s}$

Figure 5: Damage in ZERODUR at impact of pointed projectiles

The damage velocities determined with ZERODUR are plotted versus impact velocity together with the results for glasses in Figure 6. For both types of materials the damage velocity is equal to the characteristic crack velocity $v_{C}$ in the range of low impact loadings. With glasses, $v_{D}$ rises to transversal wave velocity $c_{T}$ when nucleation occurs and approaches the longitudinal wave velocity $c_{L}$ for very high loadings. The plateau in the damage velocity curve with $v_{D}=c_{T}$ was not observed in this study. With ZERODUR the damage velocity increased continuously towards $c_{L}$ for impact velocities above $90 \mathrm{~m} / \mathrm{s}$. The threshold for nucleation is higher with ZERODUR in comparison to the glasses. The damage patterns observed with glasses and ZERODUR can hardly be distinguished.

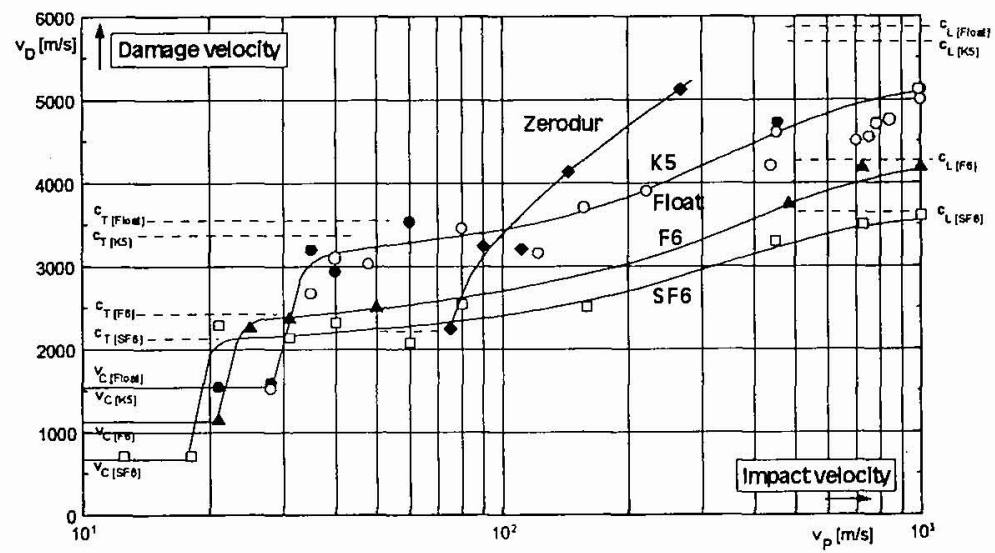

Figure 6: Damage velocity versus impact velocity for glasses and ZERODUR 


\section{BALLISTIC EFFICIENCY}

The Depth of Penetration (DOP) Test is the most frequently employed method to determine the ballistic efficiency and to establish a ranking among different ceramic materials. In a DOP-test a plate (or stack of plates) of the test material is placed on a steel block and the residual penetration $P_{R}$ of the projectile into the steel block is measured. A schematic of the DOP-test configuration and the definition of the mass efficiency factor $E_{m}$ are given in Figure 7. $P_{\text {ref }}$ is the depth of penetration into a reference target (usually armour steel), $\rho_{\mathrm{St}}$ and $\rho_{\mathrm{Cer}}$ are the densities of the reference steel and the ceramic and $T_{\mathrm{Cer}}$ is the thickness of the ceramic layer. The mass efficiency $E_{m}$ compares the weight of a reference target to the weight of a combined ceramic/steel target or other bi-layer configuration.

In the tests described here a RHA (Rolled Homogeneous Armour)-steel with a hardness of 260-270 $\mathrm{HB}$ was used as reference material. The ZERODUR plates were laterally confined by a steel frame with a glue joint of 1-2 mm between the ZERODUR plates and the steel frame. The mass efficiency value of a target is always related to the reference material and to the projectile employed in the test. The projectiles used here were tungsten cylinders with a hemispherical nose (Diameter $D=10 \mathrm{~mm}$, Length $\mathrm{L}=32 \mathrm{~mm}$, Mass $\mathrm{m}=$ $44 \mathrm{~g}$ ). The impact velocity was $1250 \mathrm{~m} / \mathrm{s}$ nominally in all tests.

The residual penetration is plotted versus the ZERODUR thickness in Figure 8a. The corresponding mass efficiencies are shown as a function of the ZERODUR weight fraction in Figure $8 \mathrm{~b}$. Earlier studies with glasses and ceramics [3] showed that a linear fit of the $E_{m}$ data gives a reliable estimation of $E_{m}$ as a function of the ceramic weight fraction. The maximum $E_{m}$ of a ceramic material is achieved when the projectile is stopped at the interface between ceramic and backing $\left(P_{R}=0\right.$, $\left.\rho_{F C e r} / \rho_{F T O T}=1\right)$. An extrapolation of the ZERODUR data yields a maximum mass efficiency $\mathrm{E}_{\mathrm{m}}$ of about 1.6. In this linear fit the data point for $\rho_{\mathrm{FCer}} / \rho_{\mathrm{FTOT}}=0.5$ was not taken into account because of yaw of the projectile.

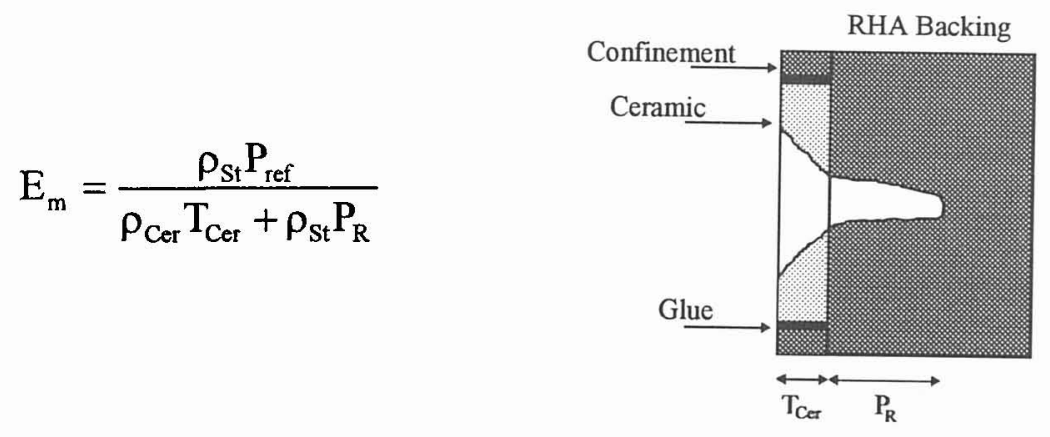

Figure 7: DOP-test configuration and definition of the mass efficiency factor

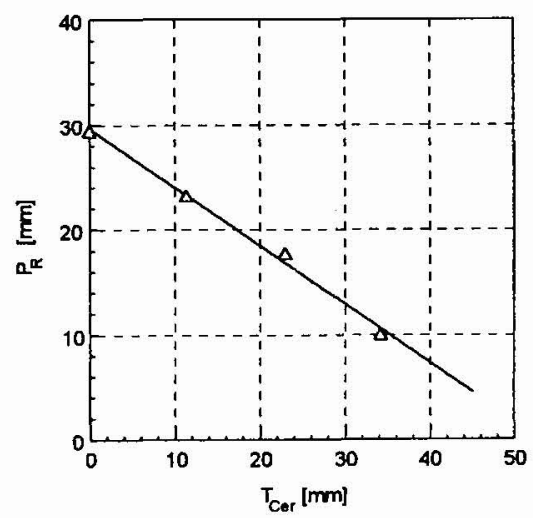

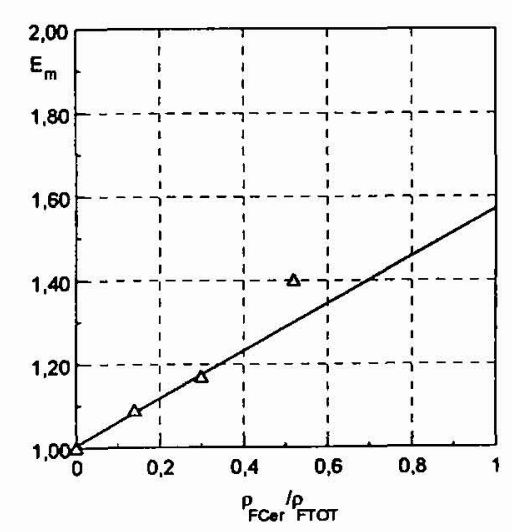

Figure 8b: Mass efficiency versus Zerodur weight fraction
Figure 8a: Residual Penetration versus ZERODUR thickness 


\section{CONCLUSION}

Although the glass-ceramic ZERODUR contains a high portion of crystalline material, the impact damage behaviour is very similar to that of glasses. All types of fracture observed with glasses were also found with ZERODUR. The hypothesis that the crystals could become nucleation sites during the action of the stress waves could not be confirmed. The number of nucleation sites per unit volume in ZERODUR did not differ significantly from the number of nucleation sites observed with glasses at similar loadings.

An estimation of the maximum achievable mass efficiency of ZERODUR yielded a value of $E_{m} \approx 1.6$. Although ZERODUR exhibits a higher hardness than soda-lime glass the mass efficiency of ZERODUR is slightly lower for the projectile-target combination employed here.

\section{Acknowledgements}

The authors are grateful to Mr. Dieter Preuß and Mr. Joerg Gonschorek who performed the experiments carefully.

\section{References}

[1] Senf H., Straßburger E., Rothenhäusler H., "Stress wave induced damage and fracture in impacted glasses", Proc. of EURO DYMAT 94, Journal de Physique IV, C8, Vol. 4, pp. 741-746, 1994

[2] Pannhorst W., "Glaskeramiken - neue Werkstoffe in unterschiedlichsten Anwendungen", Spektrum der Wissenschaft, November 1993

[3] Senf H., Straßburger E., Rothenhäusler H., Gooch W.A., Burkins M.S., "Ballistic Resistance of $\mathrm{AD} 995 \mathrm{Al}_{2} \mathrm{O}_{3}$ ceramics against short projectiles at impact velocities between $1000 \mathrm{~m} / \mathrm{s}$ and $2000 \mathrm{~m} / \mathrm{s}^{\prime \prime}$, Proc. of 15th International Symposium on Ballistics, Jerusalem, 1995 